\title{
THE CLOSING CONVERSATION STRATEGIES IN INDONESIAN TELEVISION PROGRAM
}

\author{
Agwin Degaf \\ Universitas Islam Negeri Maulana Malik Ibrahim Malang
}

\begin{abstract}
This paper aims at exploring the use of closing utterances in conversation in one of Indonesian television program. The results show that there are three types of strategies implemented close conversation and all of it is the part of positive face-saving strategies. These three strategies are: positive comment, excuse (reason), and the imperative to end strategy (imperative to end the conversation). Positive comments applied if the speakers actually enjoy the conversation, but he or she had to end it for some reasons. Excuse strategy is used to close the conversation by providing an alternative motivation or alternative explanations for the hearer which potentially exposed to the threat of the face. Lastly, imperative to end the conversation strategy applied by the use of imperative words/sentences to close the conversation, but the speaker still trying to save his/her partner's face. In general, the positive face-saving strategies used by speakers to close the conversation also consider the feelings of the hearer, giving positive comments or express a reason why a conversation should end.
\end{abstract}

Key words: Closing Conversation Strategies, Indonesian Television Program.

\section{Introduction}

People usually use opening and closing speech in conversation. Someone produce opening utterances to show that they are ready to make conversation with others or to show their intentions and to maintain social harmony. When they wanted to open conversations they say "Hey", "Hello" or "Good morning". On the other hand, the conversation is not only about to open but also need to be closed or terminated (Schegloff and Sacks in Coppock, 2005: 1). In short, people do not just stop talking and turn away each other without explanation or just leave the talk, but they have to say something that indicates they will end the conversation.

Ending a conversation implies that the other speakers are not enjoying the conversation, which then could mean that the topic is boring or annoying. Meanwhile, end the conversation can threaten the losing face for the speaker and the hearer if someone uses a strategy that is considered impolite (Coppock, 2005: 2).

Not all conversations run smoothly and cooperatively especially in closing the conversation because expressing or saying goodbye is not that simple (Hatch, 1992: 48). Speakers have to use some closing strategy because consider the hearer's feelings are important in the conversation. Coppock (2005) acknowledged that politeness strategies in close conversation are a partnership that must be done to avoid miscommunication in terminating the conversation. He believes that this strategy is designed to reduce the threat of losing the positive face, and to save face.

Based on the explanation above, the writer argues if using conversation strategies of closing is very important thing. In this study, the writer chose one of Indonesian television program namely Extravaganza as the research objects. Extravagaza is a comedy show that aired on a private television namely Trans TV. The comedy 
show was won heyday in mid of 2006. A study from Nielsen indicates if Extravaganza obtains the second highest rating of all the programs on Trans TV and ranks 6th out of all television programs in Indonesia (http://www.pikiranrakyat.com/cetak/2005/0705/ 24 / 0106.htm). What distinguishes this comedy show with other same show performers, because who plays in this program are not comedian, but they are ordinary actor and actress. Nevertheless, they could make this show into an interesting and entertaining by relying on the strength of the script and rehearsal before the show. The writer believes if the show is suitable for research on closing strategy of the conversation because in every sketch shown, Extravaganza comedians indicate the use of closing strategies in the conversation they do.

In this study, the writer chose to use the theory of closing conversation offered by Coppock (2005). Coppock classifies closing strategies into several strategies, namely: Positive Face-Saving Strategies Combined Positive and Negative Politeness, and Solidarity Strategies. In this paper, the writer will only analyze the positive face-saving strategies found in Extravaganza where Coppock divide it into 3 parts: positive comment, excuse, and the imperative to end. Based on the classification, the writer tries to analyze the utterances used by the object to close the conversation. In line with the above explanation, the writer interested in studying how positive face-saving strategies is used in closing the conversation by comedians in Extravaganza. Related to this issue, the purpose of this study is to provide a detailed explanation of the positive face-saving strategy in close conversation used by comedians of Extravaganza. The data obtained from 5 sketches of Extravaganza that are Monopoli Ajaib (Magical Monopoly), Kirimi Aku Bunga (Send Me Flowers), Toko Sepatu (Shoe Stores), Dukun Pelet (Shaman), and Negosiator (Negotiator). The scope of this study is in the closing utterances, spoken word usually used by speakers to close the topic of conversation as a sign to the hearer that the conversation will end soon. All the obtained data will be analyzed using Coppock's theory.

\section{Discussion}

This study focuses on the form of utterance to close the conversation. It means that we can say a closing speech as a closing utterance used to close the conversation. Closing speech is verbal interaction related to the conversation of others and usually occurs when a person wants to start or advised to close and end the conversation (Sambo, 2005: 7).

Closing a conversation is not easy as just saying "good bye" to the hearer only, or does it just stopped talking and turned to each other with no explanation, or just leave an ongoing conversation, but the speaker has to say something that indicates the conversation will expire (Hatch, 1992: 48). Therefore Coppock (2005) proposed several strategies used to close the conversation, namely; Positive Face-Saving Strategies, Combined Positive and Negative Politeness, and Solidarity Strategies. In this paper, we only focus on Positive Face-Saving Strategies contained in Extravaganza comedy show where Coppock divide it into 3 parts: positive comment, excuse, and the imperative to end.

\subsection{Positive Face-Saving Strategies}

Basically, positive face-saving strategies are referred as positive politeness strategy in politeness strategies because such a strategy suggests that the speaker recognizes the addressees desire to be respected. Yule (1996: 62) defines a positive face-saving strategies or strategies of politeness positive as measures to save face with regard to advance a positive person who in this case tends to be solidarity, in the sense that the two speakers, speaker and hearer wants the same thing and they have a purpose with. Coppock (2005) divides such a strategy into 3 parts: positive comment, excuse, and the imperative to end to close the conversation. 
Positive comment is the most frequently used conversation ending strategy, and is almost a direct negation of the possible implication that the other is boring or annoying, that goes along with ending a conversation (Coppock, 2005: 3). Positive comments strategy implies that the conversation is pleasant but the other does not want to continue, for example, "It was nice talking to you". That utterance shows that the speaker actually enjoying the conversation, but when the talks will continue, speakers began to feel bored or irritated, so speakers using this strategy to end the conversation. This strategy is used for face-saving strategy positively to hearer and is categorized as positive politeness strategy (positive politeness strategy) or a face-saving strategy of positive (positive face-saving strategies).

Excuse (reason) will remove the implication that one wishes to end the conversation by providing an alternative motivation, an alternative explanation for one's potentially face-threatening behavior, for example by saying "I better get back to work". From this example, the utterance can be categorized as positive politeness strategy because the speaker tried to give a reason why he could not continue the conversation (Coppock, 2005: 3).

Imperative to-end strategy is defined as a strategy which implies that the conversation should end. This strategy is more explicit than excuse strategy because using the imperative word to end the conversation. Although using the imperative word, the speaker tried to save the face of the hearer. The example of this strategy is "it looks like our time is up". Here, the speaker inserting the hearer in the utterance by using the word 'our'. This may explain that the speaker and the addressees (hearer) are cooperators. This strategy can be categorized as a positive face-saving strategy because in that utterance, the speaker and the hearer is submitted as cooperators (Coppock, 2005: 3).

In general, the positive face-saving strategies used by speakers to close the conversation also considering the feelings of the hearer, giving positive comments or express a reason why a conversation should end.

\subsection{Research Methodology}

This study used the descriptive qualitative approach, since it analyzed the data in the form of utterances descriptively based on the closing conversation strategies found in Extravaganza. It attempted to describe phenomena that happen in human life and it was hard to measure the data quantitatively since the data were in the form of words, utterances, or conversations. This study focuses on speech in closing the conversation generated by the characters in Extravaganza. Related with the data collection method, there are some steps were applied: (1) do the transcription of a conversation conducted by the actors of Extravaganza, (2) underlines the utterance containing the closing conversation, and (3) classifying the data obtained in accordance with the strategy of closing the conversation based on the Coppock's theory.

\subsection{Data Analysis}

This section will explain the data analysis in accordance with the formulation problems. Data were analyzed based on Coppock's theory of closing conversation strategies. The data in this study will use numbers, for example, the data (1) show the first utterance of the first data.

\section{Conversation 1}

Setting: At Tike's home

Participants: Indra (the man who is looking for a mate), Sogi (acting as a child of Tike)

Situation: $\quad$ Indra is looking for a mate; incidentally Tike who was a friend of his mother has three children named the Rose, Jasmine and Cambodia Flowers. Indra refused to be paired with Rose and Jasmine. Finally Tike offers 
her last child, namely Cambodia.

Indra : "Wah, bunga apa bu? Kok bantet? Well, what kind of flower, mom? too fat?

Sogi : "Bunga Kamboja"

Cambodia Flowers

Indra : "Gak deh bu, saya takut. Saya pulang aja, bu" (1.1)

No ma'am, I'm afraid. I go back,

mom

Utterance (1.1) I go back mom, indicating that Indra wanted to end her conversation with Sogi. He also uses an alternative explanation by saying that he is afraid. It is to make the hearer understand the reasons for him to end the conversation. "I go back" also implies that the speaker wants to end the conversation. This strategy is categorized as an excuse in a positive facesaving strategy as speakers tried to give reasons to his partner about why he had to close the conversation.

\section{Conversation 2}

Setting: At the jewelry store

Participants: Tora (robbers), Julie (Sandra)

Situation: Tora was robbing the jewelry stores, Julie was the store keeper. Because the police came to arrest him, Tora finally hostage Julie. In the end, the ring which is worn by Tora is used by him to propose Julie.

Tora: Iya, ayo kita seluar sandro-medo. Saya ingin menyatakan bahwa kamu telah merebut hatiku yang hina-bina ini. Sudikah kiranya kamu menikahiku?

Yeah, let's go sandro-medo.I would like to declare that you have stolen my humble heart. Presumably, will you marry me?

Julie : $\quad$ Mau
I want

Tora: Baik, kalo gitu kita ke KUA. Let's go. (2.1)

Well, we go to KUA. Let's go

Utterance (2.1) lets' go categorized as imperative to close the conversation (the imperative to-end) in a positive face-saving strategies. Tora implies to end the conversation because he wanted to go to KUA. Although using the word imperative, the speaker tried to save the face of the hearer. From the utterance above, the speakers includes the addressees in the utterances by using the word 'us' (let us go). This may explain that the speaker and the addressees are cooperators. This strategy can be categorized as a positive face-saving strategy in the utterance because it was submitted that the speaker and the addressees are cooperators.

\section{Conversation 3}

Setting: in a shoe store

Participants: Roni (buyer), Tora (the seller)

Situation: Roni buying shoes in Tora's store. Incidentally the shoes requested by Roni are the shoes that are the most advanced because it can be used as a mobile phone.

Tora : Halo, apa kabar? Ah, Cuma iseng saja mau ngabisin pulsa, ntar gue nelpon lagi yah? Cay.. dah..

Hello, how are you? Ah, Just for fun, just want splurging credits, I will call you later, okay? bye...

Roni : Wah, canggih nih sepatu, pak. Yang canggih-canggih gini biasanya hanya ada di extravaganza.

Whoa, very sophisticated shoes, sir. This kind of sophisticated things is usually only exist in Extravaganza

Tora : Ini pak satu pasangnya lagi.

This is the other pair, sir

Roni : Ini aku langsung bayar, deh. (3.1) 
This is (the money), I instantly paid for it

Utterance (3.1) I instantly pay, could be categorized as an excuse in a positive face-saving strategies. Excuse (reason) will remove the implication that one wishes to end the conversation by providing an alternative motivation, an alternative explanation for one's potentially facethreatening behavior. In the utterance above, the speaker tried to remove the implication that he did not want to linger a conversation by saying that he would immediately pay for the shoes he wants. If the speaker says something else, such as asking price, for example, of course the conversation will continue. The utterance $I$ instantly paid can be categorized as positive politeness strategy because the speaker tried to give a reason why he could not continue the conversation.

\section{Conversation 4}

Setting: In a shoe store

Participants: Mieke (buyer), Tora (the seller)

Situation: Mieke are buying shoes in Tora's store. The shoes that asked by her is the one that make her seem higher.

Tora: Silahkan dicoba. Dijamin tinggi.

higher

Please try. Guaranteed (you look)

Mieke: Gak usah dicoba deh, nih bayar. (4.1)

No need to try, I pay (the shoes)

Utterance (4.1) No need to try, I pay implies that the speaker wants to end the conversation. The speech can be categorized as an excuse in a positive face-saving strategy. In this case, the speaker uses alternative motivation for the hearer that potentially exposed by the face-threatening. The utterance above could make the hearer understands the reasons to end the conversation. From this example, the utterance can be categorized as positive politeness strategy because the speakers tried to give a reason why he could not continue the conversation.

\section{Conversation 5}

Setting: In a shoe store

Participants: Santoro (buyer), Tora (the seller), and Tike (Tora's employee)

Situation: Santoro protested to Tora because the shoes he bought turned out to make him being chased by girls, and consequently Santoro's girlfriend dumped him.

Tora: Mas sampe dikejar cewek-cewek?

You were chased by girls?

Tike: Wah, mas harusnya senang dong!

Well, you should be happy right!

Santoro: Seneng apa? Tuh, lihat tuh ceweknya! (Aming masuk)

What kind of happiness? See the girl! (Aming entry)

Tora: Kabur... (5.1)

\section{Let's escape...}

Utterance (5.1) lets escape... is categorized as imperative to end the conversation in a positive face-saving strategy. Although using the imperative word, the speaker tried to save face of the hearer. In the utterance above, the speaker implicitly invites his partners to go because of Aming's arrival. This may explain that the speaker and the addressees are cooperators. This strategy can be categorized as a positive face-saving strategy because in that utterance, the speaker and the hearer is submitted as cooperators

\section{Conversation 6}

Setting: At shaman's home

Participants: Sogi (patient), Ronald (shaman)

Situation: Sogi asks spells to the shaman (Ronald) to make his girlfriend back. Sogi feels his girlfriend had changed and stayed away from him.

Sogi: Aduh kepala saya dingin 


\section{Oh my head is cold}

Ronald: Aduh, sampai pitak. Bagaimana rasanya?

it feel?

Oops, until the bald spot. How does

Sogi: Migrain mbah

Migraine headache, mbah

Ronald: Itu efek samping. Setelah itu kamu pulang temui pacar kamu, lengket.

It's a side effect.After that, you go home to meet your girlfriend, sticky

Sogi: Oke mbah kalo gitu mbah (kasih uang) terima kasih ya mbah. (6.1)

Okay, (giving money) thanks mbah

Speech (6.1) thanks mbah is categorized as positive comment (positive comment) in a positive face-saving strategy. The utterance shows that the speaker is actually really enjoyed the conversation, but he wanted to end it because he must go. This kind of strategy is a direct negation of the possible implication that the other is boring or annoying, that goes along with ending a conversation. This strategy is used for facesaving strategy positively to the hearer and is categorized as a positive face-saving strategy. The use of positive comments in conversations helps the speaker to close the conversation. Although the speaker wants to end the conversation, he tried to save the hearer's face and try to make the hearer feels happy, so it makes the speaker close the conversation easily.

\section{Conversation 7}

Setting: At shaman's home

Participants: Tora (the patient), Ronald (shaman)

Situation: Tora visited Ronald and ask spells to get a woman who he loved. However, Ronald also loved that woman so that he lied to Tora by saying that the woman is not suitable for Tora.

Tora: Tidak cocok dengan dia ya, mbah? Am I not suitable for her?
Ronald: Saya sarankan sebagai dukun, jangan sama dia deh. Gak cocok. Cari yang lain aja.

I suggest as a shaman, do not choose her. Not suitable. Find another girl Tora: Yaudah deh. Saya pulang ya mbah. (7.1)

\section{Okay, then. I went home mbah}

Utterance (7.1) I went home mbah is categorized as an excuse (reason) in a positive face-saving strategy. This implies that the speaker wants to end the conversation by providing an alternative explanation to the hearer to avoid the possibility of losing face. The utterance from Tora, explains why he had to close the conversation. It is because he wanted to go home, and the utterance can be categorized as positive politeness strategy because the speakers tried to give a reason why he cannot continue the conversation. It helps the speaker to convey his intentions to the hearer by using polite language to end the conversation.

\section{Conversations 8}

Setting: In the living room

Participants: Sogi (kid), Virnie (mother)

Situation: $\quad$ Sogi was playing monopoly with Aming and Tike. Suddenly, his mother (Virnie) comes to give him money which left behind.

Virnie: Tadi pagi, uang jajan kamu ketinggalan nih.

money

This morning, you forgot your Sogi: Uang jajan aku?

\section{My money?}

Virnie: He em.. mama pergi dulu ya (8.1)

\section{Yes.. Mama go first}

Utterance (8.1) Mama go first is categorized as excuse (reason) in a positive face-saving strategy. This implies that the speaker wants to end the conversation by providing an alternative explanation to the hearer to avoid the possibility of losing face. 
Degaf, The Closing Conversation Strategies In...

Here, the speaker provides an alternative explanation that she had to go, so she cannot continue the conversation. The utterance can be categorized as positive politeness strategy because the speaker tried to give a reason why she could not continue the conversation. The use of closing strategies above implies that it helps the speaker to end the conversation by explaining to the hearer why a conversation should end.

\section{Conclusion}

After conducting an analysis of the strategies used in the closing conversation in Extravaganza sketches. It can be concluded that there are three types of strategies implemented close conversation and all of it, are the part of positive face-saving strategies. These three strategies are: positive comment, excuse (reason), and the imperative to end strategy (imperative to end the conversation). Positive comments applied if the speakers actually enjoy the conversation, but he or she had to end it for some reasons. Excuse strategy is used to close the conversation by providing an alternative motivation or alternative explanations for the hearer which potentially exposed to the threat of the face. Lastly, imperative to end the conversation strategy is applied by the use of imperative words/sentences to close the conversation, but the speaker still trying to save his/her partner's face. In general, the positive facesaving strategies used by speakers to close the conversation also consider the feelings of the hearer, giving positive comments or express a reason why a conversation should end.

\section{References:}

Brown, Gillian and George Yule. 1989. Discourse Analysis. Sydney: Cambridge University Press.

Coppock, Liz. 2005. Politeness Strategies in Conversation Closings. Unpublished paper available online at http: // www. stanford. edu / Coppock / face. pdf.

Goody, E. N. 1996. Questions and Politeness. London: Cambridge University Press.

Grundy, Peter. 2000. Doing Pragmatics. London: Arnold.

Hatch, Evelin. 1992. Discourse and Language Education. London: Cambridge University Press.

Kusumawati, Christina Dewi. 2006. The Flouted maxims that create the funniness in 'Extravaganza'. Unpublished thesis. Surabaya: Petra Christian University.

Leech, Geoffrey. 1983. Principles of Pragmatics. London and New York: Longman.

Sambo, Agustina. 2005. The Closing utterances in Conversation Used by Young People in Rantepao, Tana Toraja. Unpublished thesis. Surabaya: Petra Christian University. 